\title{
AUTHORITARIAN PARENTING STYLE WITH AGGRESSIVE BEHAVIOR OF 5-6 YEARS OLD
}

\author{
Defanny Fauziyah Pratiwi' ${ }^{1)}$, Ruli Hafidah'), Adriani Rahma ${ }^{3)}$ \\ PG-PAUD, FKIP Universitas Sebelas Maret Surakarta \\ defannyfp@gmail.com
}

\begin{abstract}
The family is the place where the education process takes place. Parents hold the first and foremost role for child development which is an important task and cannot be separated from various challenges. Parenting style is one of the behavioral factors and actions of children since early to adulthood. The purpose of this study was to determine the relationship between authoritarian parenting and the aggressive behavior of children aged 5-6 years. Sampling using purposive sampling technique amounted to 37 parents and children aged 5-6 years in Mojolegi, Teras, Boyolali. Data in this study were obtained from questionnaires. The technique of analyzing questionnaire items using the total corrected item-total correlation. The results showed that there was a significant relationship between authoritarian parenting and the aggressive behavior of children with $r=0.996$ with $p=0.000$ with the help of SPSS 16 for windows. This value shows a positive result which means that the higher the authoritarian parenting style, the higher the child's aggressive behavior.
\end{abstract}

Keywords: authoritarian parenting, aggressive behavior, children aged 5-6 years

\section{POLA ASUH OTORITER DENGAN PERILAKU AGRESIF ANAK USIA 5-6 TAHUN}

\begin{abstract}
Abstrak: Keluarga merupakan tempat awal berlangsungnya proses pendidikan. Orangtua memegang peran pertama dan utama bagi tumbuh kembang anak yang merupakan tugas penting dan tidak lepas dari berbagai tantangan. Gaya pengasuhan orangtua menjadi salah satu faktor perilaku dan tindakan anak semenjak dini hingga dewasa kelak. Tujuan dalam penelitian ini untuk mengetahui hubungan pola asuh otoriter dengan perilaku agresif anak usia 5-6 tahun. Pengambilan sampel menggunakan teknik purposive sampling berjumlah 37 orang tua dan anak usia 5-6 tahun di Mojolegi, Teras, Boyolali. Data dalam penelitian ini diperoleh dari kuisioner. Teknik analisis item kuesioner menggunakan rumus corrected item-total correlation. Hasil penelitian menunjukkan bahwa terdapat hubungan yang signifikan antara pola asuh otoriter dengan perilaku agresif anak dengan nilai $r=0,996$ dengan $p=$ 0,000 dengan bantuan SPSS 16 for windows. Nilai tersebut menunjukkan hasil yang positif yang berarti semakin tinggi pola asuh otoriter maka semakin tinggi pula perilaku agresif anak.
\end{abstract}

Kata Kunci: pola asuh otoriter, perilaku agresif, anak usia 5-6 tahun

\section{PENDAHULUAN}

Undang-Undang Nomor 20

Tahun 2003 [1] mendefinisikan pendidikan adalah usaha sadar dan terencana untuk mewujudkan suasana belajar dan proses pembelajaran agar peserta didik secara aktif mengembangkan potensi dirinya untuk memiliki kekuatan spiritual, keagamaan, pengendalian diri, kepribadian, kecerdasan, akhlak mulia, serta keterampilan yang diperlukan dirinya, masyarakat, bangsa, dan negara. Pendidikan merupakan hal yang penting bagi setiap individu. Proses pendidikan dapat diperoleh kapan dan dimana saja. Salah satunya dalam lingkungan keluarga.

Kecenderungan menyuruh, memerintah, memaksa, membatasi, 
mengatur, menentukan, menguasai cenderung lebih mendominasi apa yang dilakukan oleh orangtua (Murdoko, 2017) [2]. Hal ini terjadi karena orangtua memiliki tujuan memuaskan ambisi yang besar terhadap anaknya tetapi dengan cara yang penuh dengan aturan dan paksaan. Hal tersebut menjadikan tidak sedikit orangtua yang menerapkan pola asuh otoriter. Baumrind (Casmini, 2007) [3] berpendapat bahwa pola asuh otoriter adalah pola pengasuhan dengan orangtua yang tinggi tuntutan namun rendah tanggapan. Orangtua otoriter selalu menuntut tanpa memahami keinginan anak.

Chen, Dong, dan Zou (Bibi, 2013) [3] menjelaskan bahwa orangtua dengan gaya pengasuhan otoriter menjadikan anak berperilaku agresif yang lebih tinggi dibandingkan dengan perilaku prososial yang lebih rendah. Anak dengan pengasuhan otoriter lebih sering berperilaku agresif.

Lebih lanjut, Lestari (2012) [4] mendefinisikan gaya pengasuhan otoriter merupakan pengasuhan dilakukan orangtua yang selalu berusaha membentuk, mengontrol, mengevaluasi perilaku dan tindakan anak agar sesuai dengan aturan standar. Aturan yang diberikan biasanya bersifat mutlak yang dimotivasi oleh semangat teologis dan diberlakukan dengan otoritas yang tinggi. Robinson et al (1995) [5] menetapkan ciri internal yang mencerminkan praktik pengasuhan otoriter, yaitu sebagai berikut: adanya permusuhan verbal, orangtua memberikan hukuman fisik, anak mendapat hukuman yang tidak realistis, orangtua memiliki kekuatan untuk mengarahkan atau memerintah.

Hal tersebut juga sesuai fakta di lapangan saat ini, berdasarkan observasi prapenelitian di keluarahan Mojolegi peneliti mendapat informasi dari salah satu guru yang menjelaskan ada beberapa orangtua yang menerapkan pola asuh otoriter, seperti: orangtua yang selalu menuntut anak untuk belajar dan belajar tanpa memberi waktu bermain di rumah, ada pula orangtua yang memberi jam tambahan diluar sekolah seperti les membaca, menulis, dan berhitung. Hal tersebut terjadi karena ambisi orangtua untuk menjadikan anak nomor satu diantara teman-temannya namun kurang memperhatikan kebutuhan dan keinginan anak. Peneliti juga menemukan beberapa perilaku agresif anak-anak usia 5-6 tahun berbedabeda, yaitu: pada jam istirahat peneliti mengamati ada anak yang berkatakata kasar dengan nada tinggi kepada teman-temannya, ada anak yang tidak suka dengan temannya kemudian dia memukul dan menendang anak yang tidak disukai tersebut.

Seagal (Arriani, 2014) [6] berpendapat bahwa agresif merupakan perilaku yang tidak seharusnya dan menimbulkan konsekuensi yang serius baik untuk siswa maupun untuk orang lain yang ada dilingkungannya. Anak yang agresif melakukan hal diluar aturan yang dapat merugikan diri sendiri maupun orang disekitar anak.

Buss dan Perry (1992) [7] menjelaskan terdapat empat dimensi agresi yang dapat digunakan untuk melihat jenis perilaku agresif, sebagai berikut: pertama agresi fisik merupakan kecenderungan individu untuk melakukan serangan secara fisik sebagai ekspresi kemarahan, kedua agresi verbal yaitu kecenderungan untuk menyerang orang lain atau memberi stimulus yang merugikan dan menyakitkan melalui kata-kata atau penolakan, ketiga kemarahan merupakan wujud emosi berupa dorongan fisiologis sebagai tahap persiapan agresi, dan keempat permusuhan yaitu perasaan ketidakadilan sebagai wujud dari proses berpikir. 
Sesuai informasi di lapangan yang diperoleh dari salah satu guru bahwa benar ada beberapa anak yang berperilaku agresif. Perilaku agresif tersebut antara lain seperti, ketika ada anak yang sedang bertengkar dan anak agresif tersebut akan terus menyerang samapai anak merasa sudah menang, ada pula anak yang senang mencubit temantemannya tanpa alasan dengan intensitas waktu yang sering. Perilaku agresif ini sering muncul keika belajar di dalam kelas, ketika anak sedang bermain, sering kali anak saling mengejek, dan berebut mainan. Sikap anak yang mendapat perlakuan agresif yaitu ada yang menangis, membalas, melaporkan kepada guru atau orang dewasa disekitarnya, dan juga ada anak yang hanya diam. Solusi yang diberikan guru ketika menghadapi anak yang emosinya tidak terkontrol yaitu langsung memeluk anak dan mengucapkan kalimat istighfar.

\section{METODE PENELITIAN}

Penelitian ini dilaksanakan di TK kelurahan Mojolegi, Kecamatan Teras, Kabupaten Boyolali. Penelitian dilakukan pada bulan Desember sampai November 2018. Penelitian ini termasuk penelitian korelasional yaitu untuk mengetahui ada-tidaknya hubungan antara dua variabel.

Pengambilan

menggunakan teknik Purposive Sampling berjumlah 37 orang tua dan anak usia 5-6 tahun. Data dalam penelitian ini diperoleh dari kuisioner. Skala yang digunakan untuk mengukur pola asuh orang tua menggunakan Parenting Practices Questionnaire yang diadaptasi dari Robinson et al (1995) [6] terdiri dari 20 item. Skala yang digunakan untuk mengukur perilaku agresif menggunakan kuisioner yang diadaptasi dari jurnal Buss dan Perry (1992) [8] terdiri dari 27 item.

Data yang diperoleh dari hasil uji coba kemudian diuji analisis item menggunakan bantuan SPSS 16 for windows yang menghasilkan angka pada kolom corrected item-total correlation. Berdasarkan dari uji analisis item pada instrumen pola asuh otoriter menghasilkan 13 item yang dapat digunakan. Sedangkan pada instrumen perilaku agresif anak usia 5-6 tahun menghasilkan 22 item yang dapat digunakan.

Uji reliabilitas dalam penelitian ini dilakukan dengan menggunakan teknik Formula Alpha Cronbach, dengan aplikasi SPSS 16 untuk mencari reliabilitas instrumen. Peneliti menggunakan skala Likert yang skornya memiliki rentang 1 sampai 5. Hasil uji reabilitas pola asuh otoriter menghasilkan angka 0,741 dan hasil uji reabilitas perilaku agresif menghasilkan angka 0,908.

Teknik analisi data yang digunakan dalam penelitian ini adalah uji spearman rho dengan menggunakan bantuan SPSS 16 for windows dengan ketentuan yang digunakan adalah jika hasil nilai signifikan yang didapat lebih kecil dari 0,05 maka terdapat korelasi antara variabel.

\section{HASIL DAN PEMBAHASAN Hasil Penelitian}

Instrumen pola asuh otoriter yang disajikan dalam bentuk kuesioner memiliki 13 butir item dengan skor jawaban 1 s.d 5 dengan pilihan jawaban tidak pernah, jarang, kadang-kadang, sering, dan selalu. Distribusi data pada variabel pola asuh otoriter ini diukur dan disajikan menggunakan SPSS 16 for windows. Distribusi data pada pola asuh otoriter ini menyajikan mean dengan nilai 33.59, median dengan nilai 34.00, modus dengan nilai 35.00 , standart deviasi 4.15, nilai maximum 43.00, dan nilai minimum 26.00. Sehingga dapat diperoleh hasil pengkategorian pengukuran pola asuh otoriter menjadi tiga kategori, yaitu: 
Tabel 1. Data Kategorisasi Tingkat Pola Asuh Otoriter

\begin{tabular}{ccc}
\hline $\begin{array}{c}\text { Tingkat Pola } \\
\text { Asuh Otoriter }\end{array}$ & Skor & Jumlah Anak \\
\hline Rendah & $\mathrm{X}<29.45$ & 6 \\
Sedang & $\begin{array}{c}29.45 \leq \mathrm{X} \\
\leq 37.75\end{array}$ & 20 \\
& $\mathrm{X}>37.75$ & 11 \\
\hline
\end{tabular}

Data kategorisai tingkat pola asuh otoriter terdiri dari 37 orangtua sebagai sampel penelitian. Menunjukkan bahwa terdapat 6 orangtua yang tergolong rendah yang artinya skor total kurang dari 29.45. Terdapat 20 orangtua yang tergolong sedang yang artinya skor total kurang dari sama dengan 29.45 dan kurang dari 37.75 . Terdapat 11 orangtua tergolong tinggi dengan skor total lebih dari 37.75. Selanjutnya penjelasan mengenai distribusi data perilaku agresif anak usia 5-6 tahun.

Instrumen perilaku agresif yang disajikan dalam bentuk angket memiliki 22 butir item dengan skor jawaban 1 s.d 5 dengan pilihan jawaban tidak pernah, jarang, kadang-kadang, sering, dan selalu. Distribusi data pada variabel perilaku agresif anak ini diukur dan disajikan menggunakan SPSS 16 for windows. Secara terperinci dapat dilihat pada lampiran. Distribusi data pada perilaku agresif anak ini menyajikan mean dengan nilai 64.54 , median dengan niali 64.00, modus dengan nilai 59.00, standart deviasi 12.37 , nilai maximum 97.00, dan nilai minimum 43.00, sehingga dapat diperoleh hasil pengkategorian pengukuran perilaku agresif menjadi tiga kategori, yaitu:

Tabel 2. Data Kategorisasi Tingkat Perilaku Agresif

\begin{tabular}{ccc}
\hline $\begin{array}{c}\text { Tingkat } \\
\text { Perilaku }\end{array}$ & Skor & $\begin{array}{c}\text { Jumlah } \\
\text { Orangtua } \\
\text { Agresif }\end{array}$ \\
\hline Rendah & $\mathrm{X}<52.5$ & 6 \\
Sedang & $52.5 \leq \mathrm{X} \leq 76.8$ & 18 \\
Tinggi & $\mathrm{X}>76.8$ & 13 \\
\hline
\end{tabular}

Data kategorisai tingkat perilaku agresif terdiri dari 37 anak sebagai sampel penelitian. Menunjukkan bahwa terdapat 6 anak yang tergolong rendah yang artinya skor total kurang dari 52.5. Terdapat 18 anak yang tergolong sedang yang artinya skor total kurang dari sama dengan 52.5 dan kurang dari 76.8. Terdapat 13 anak tergolong tinggi dengan skor total lebih dari 76.8.

Berdasarkan hasil uji hipotesis diketahui bahwa besarnya koefisien korelasi antara variable pola asuh otoriter dengan perilaku agresif anak sebesar 0.996. Hasil signifikansi = 0,000, karena signifikansi $<0,05$ maka hipotesis diterima yang artinya ada hubungan antara variabel pola asuh otoriter dan perilaku agresif.

Hasil tersebut menunjukkan nilai positif dan memiliki hubungan sangat kuat yang berarti semakin tinggi pola asuh otoriter semakin tinggi pula perilaku agresif. Begitu pula sebaliknya.

Nilai total dari hasil compare mean sebesar 64.5. Secara keseluruhan total rata-rata perilaku agresif dengan anak berjenis kelamin perempuan sebesar 63.8 dan total rata-rata perilaku agresif dengan anak berjenis laki-laki sebesar 65.0. Dimana perilaku agresif anak laki-laki menunjukkan nilai total rata-rata lebih tinggi dari nilai total keseluruhan, dibandingkan dengan nilai total ratarata anak perempuan. Sehingga dapat menunjukkan bahwa anak laki-laki lebih banyak yang berperilaku agresif dibandingkan dengan anak perempuan.

Berikut tabel hasil compare mean antara jenis kelamin dengan perilaku agresif anak.

Tabel 3 Compare Mean Antara Jenis Kelamin dengan Perilaku Agresif

\begin{tabular}{cccc}
\hline $\begin{array}{c}\text { Jenis } \\
\text { Kelamin }\end{array}$ & Mean & N & Std. Deviation \\
\hline Perempuan & 63.8000 & 15 & 11.37792
\end{tabular}




\begin{tabular}{llll} 
Laki-laki & 65.0455 & 22 & 13.17457 \\
\hline Total & 64.5405 & 37 & 12.32791 \\
\hline
\end{tabular}

\section{Pembahasan}

Pengujian hasil hipotesis menggunakan uji korelasi spearman rho karena kedua variabel tersebut merupakan data ordinal. Berdasarkan hasil penelitian yang telah dilaksanakan menunjukkan ada hubungan pola asuh otoriter dengan perilaku agresif anak usia 5-6 tahun. Artinya, uji hipotesis "terdapat hubungan antara pola asuh otoriter dengan perilaku agresif anak usia 5-6 tahun" diterima. Analisis data dari hasil penelitian ini juga menunjukkkan tingkat koefisien korelasi atau keeratan hubungan antar kedua variabel berada pada tingkat hubungan yang sangat kuat/tinggi. Abdurahman dan Muhidin (2011) [9] menjelaskan bahwa angka indeks korelasi bertanda plus (+) maka korelasi tersebut menunjukkan hasil positif atau serah, sehingga dapat diartikan bahwa semakin tinggi tingkat pola asuh otoriter maka semakin tinggi pula perilaku agresif anak, sebaliknya semakin rendah tingkat pola asuh otoriter maka semakin rendah pula perilaku agresif anak.

Hasil ini diperkuat dengan penelitian yang telah dilakukan oleh Zazimah (2015) [10] mengemukakan bahwa bahwa pola asuh otoriter memberikan pengaruh terhadap tingkat agresivitas anak usia 4-5 tahun sebesar $54,9 \%$. Hasil penelitian ini sejalan dengan penelitian yang dilakukan oleh Chen, Dong, dan Zou (Bibi, 2013) [4] menjelaskan bahwa perilaku agresif muncul lebih tinggi dibandingkan dengan perilaku prososial yang lebih rendah yaitu berhubungan dengan orangtua dengan gaya pengasuhan otoriter. Pola asuh otoriter merupakan salah satu faktor munculnya perilaku agresif pada anak.

Berdasarkan penelitian dan pendapat di atas dapat disimpulkan bahwa pola asuh otoriter dapat memberikan dampak pada perilaku agresif anak. Terlihat dari nilai yang ada pada koefisien korelasi termasuk kategori sangat kuat. Hubungan pola asuh otoriter orangtua memberikan sumbangan besar dalam perilaku agresif anak. Semakin tinggi pola asuh otoriter semakin tinggi perilaku agresif anak, begitu pula sebaliknya semakin rendah pola asuh otoriter semakin rendah pula perilaku agresif anak.

Smith (Ahadi dkk., 2014) [11] menjelaskan bahwa anak-anak dari orang tua dengan gaya pengasuhan otoriter cenderung menarik diri. Anak-anak ini kurang berinisiatif dan mereka akan menjadi agresif. Selain itu, Thompson (2003) [12] menerangkan bahwa rasa frustrasi yang dianggap sepele oleh orang dewasa, bisa merupakan masalah besar bagi anak. Bahkan menyebabkan timbulnya respon fisik. Oleh karena frustrasi itu juga, kadangkadang anak memukul, menggigit, atau mendorong anak lain. Hal tersebut menjadikan anak memiliki ciri-ciri anak berperilaku agresif.

Temuan tambahan dalam penelitian ini menunjukkan kecenderungan jenis kelamin terhadap munculnya perilaku agresif. Temuan tambahan dari penelitian ini menunjukkan bahwa perilaku agresif anak laki-laki menunjukkan nilai compare mean lebih tinggi dibandingkan dengan nilai compare mean perilaku agresif anak perempuan. Berarti anak laki-laki memiliki kemungkinan yang lebih besar munculnya perilaku agresif. Hal ini sejalan dengan teori yang dipaparkan oleh Anantasari (2006) [13] bahwa gen merupakan faktor yang ikut mempengaruhi perilaku agresif pada manusia, dan pria cenderung lebih agresif karena memiliki kromosom XYY. Selain itu 
penelitian yang dilakukan oleh Pathirana (2015) [14] mengemukakan bahwa pengamatan terungkap beberapa anak (kebanyakan anak laki-laki) menikmati tindakan agresor yaitu seperti, menyerang atau berteriak kemudian melarikan diri dan anak lain (kebanyakan perempuan) tampaknya tertekan dan takut pada anak laki-laki yang mengambil peran agresor yang dianggap menyenangkan.

Kesimpulan pada penelitian tentang hubungan pola asuh otoriter dengan perilaku agresif pada anak menunjukkan nilai hubungan pada koefisien sangat kuat. Hubungan yang terjadi adalah searah, artinya semakin tinggi pola asuh otoriter maka semakin tinggi pula perilaku agresif pada anak begitu pula sebaliknya semakin rendah pola asuh otoriter makan semakin rendah pula perilaku agresif anak.

Selain itu, anak laki-laki memiliki kemungkinan lebih besar dalam memunculkan perilaku agresif dibandingkan dengan anak perempuan. Anak laki-laki akan lebih sering berperilaku agresif karena dianggap hal yang menyenangkan sedangkan anak perempuan menunjukkan lebih sedikit yang memunculkan perilaku agresif dan lebih merasa ketakutan dengan mereka yang berperilaku agresif.

\section{SIMPULAN}

Berdasarkan hasil analisis data, pengujian hipotesis yang diajukan dan pembahasan, maka dapat diambil kesimpulan, yaitu ada hubungan positif atau searah antara pola asuh otoriter dengan perilaku agresif anak usia 5-6 tahun. Hubungan positif atau searah ini diartikan bahwa semakin tinggi tingkat pola asuh otoriter maka semakin tinggi pula perilaku agresif anak, sebaliknya semakin rendah tingkat pola asuh otoriter maka semakin rendah pula perilaku agresif anak. Penelitian ini menunjukkan perilaku agresif anak lakilaki lebih tinggi dibandingkan dengan perilaku agresif anak perempuan. Berarti anak laki-laki lebih sering menunjukkan perilaku agresif dibandingkan dengan anak perempuan.

Berdasarkan simpulan yang telah dipaparkan oleh peneliti, dimungkinkan bertambahnya informasi tentang pola asuh otoriter yang mempengaruhi perilaku agresif anak. Selain itu, juga memberikan gambaran terkait kajian ilmu mengenai hubungan pola asuh otoriter dengan perilaku agresif anak. Hasil penelitian ini juga dapat memberikan informasi tambahan pada orang tua mengenai pola asuh di dalam keluarga. Berdasarkan hasil penelitian, peneliti memberikan saran kepada pihak yang terkait antara lain, sebagai berikut:

Pertama untuk orang tua, hendaknya orangtua membekali diri mengenai pengetahuan pola asuh, karena pola asuh dapat menentukan perilaku anak dan akan terbawa hingga anak tumbuh dewasa.

Kedua guru hendaknya mengetahui latar belakang dan lingkungan anak di rumah sebagai bahan pertimbangan dalam proses pembelajaran, sehingga guru dapat mencegah terjadinya perilaku agresif pada anak. Guru juga dapat melaksanakan seminar parenting dengan mengundang orangtua anak.

Ketiga peneliti selanjutnya dapat menindaklanjuti penelitian ini dengan memperbanyak populasi penelitian dan referensi yang lebih mendalam. Perlunya penelitian lanjutan dengan lebih mendalam untuk membuktikan faktor selain pola asuh otoriter yang dapat mempengaruhi perilaku agresif anak usia 5-6 tahun.

\section{DAFTAR PUSTAKA}

[1] Undang-Undang Republik Indonesia. (2003). Nomor 20 Tahun 2013 Tentang Sistem Pendidikan 
Nasional. Kementerian Pendidikan dan Kebudayaan.

Kabupaten Bantul. UNNES: Semarang.

[2] Murdoko, W. E. (2017). Parenting with leadership (peran orangtua dalam mengoptimalkan dan memberdayakan potensi anak). Jakarta: PT Gramedia.

[3] Casmini. (2007). Emotional parenting. Yogyakarta: P_idea.

[4] Bibi, F., et al. (2013). Contribution of parenting style in life domain of children. Journal of Humanities And Social Science, 12 (2), 91-95.

[5] Lestari, S. (2012). Psikologi keluarga. Jakarta: Kencana Prenada Media Group.

[6] Robinson, et al. (1995). Authoritative, authotarian, and permisive parenting practices: development of a new massure. Psycological Reports, 77, 819-830.

[7] Arriani, F. (2014). Perilaku agresif anak usia dini. Jurnal Pendidikan Usia Dini, 8 (2), 270-280.

[8] Buss, H. A \& Perry, M. (1992). The aggression questionnaire. Journal of Personality and Social Psychology, 63 (2), 452-459.

[9] Abdurrahman dan Muhidin. (2011). Panduan praktis memahami penelitian. Bandung: Pustaka Setia.

[10] Zazimah. (2015). Pengaruh pola asuh otoriter terhadap tingkat agresivitas anak usia 4-5tahun di RA Insan Harapan, Kecamatan Pandak,

[11] Ahadi, et al. (2014). The relationship between parenting styles and adolescent's identity and aggression. Indian Journal of Fundamental and Applied Life Sciences, 4, (S3), 1171-1178.

[12] Thompson, J. (2003). Tolddcare: pedoman merawat balita. Jakarta: Erlangga.

[13] Anantasari. (2006). Menyikapi perilaku agresif anak. Yogyakarta: Kanisius.

[14] Pathirana, B. (2016). Aggressive behaviors of sri lankan preschool children: a mixed method study. The International Journal of Indian Psychology, 3 (57), 66-81. 